\title{
Lactoperoxidase: physico-chemical properties, occurrence, mechanism of action and applications
}

\author{
Klaas D. Kussendrager* and A. C. M. van Hooijdonk \\ DMV-International, R\&D Center, PO Box 13, 5460 BA Veghel, The Netherlands
}

\begin{abstract}
Lactoperoxidase (LP) is one of the most prominent enzymes in bovine milk and catalyses the inactivation of a wide range of micro-organisms in the lactoperoxidase system (LP-s). LPsystems are also identified as natural antimicrobial systems in human secretions such as saliva, tear-fluid and milk and are found to be harmless to mammalian cells. The detailed molecular structure of LP is identified and the major products generated by the LP-s and their antimicrobial action have been elucidated for the greater part. In this paper several aspects of bovine LP and LP-s are discussed, including physico-chemical properties, occurrence in milk and colostrum and mechanisms of action. Since the introduction of industrial processes for the isolation of LP from milk and whey the interest in this enzyme has increased considerably and attention will be paid to potential and actual applications of LP-systems as biopreservatives in food and other products.
\end{abstract}

Lactoperoxidase: LP-system: Antimicrobial properties: Applications

\section{Introduction}

Lactoperoxidase (EC 1.11.1.7) (LP) is a member of the peroxidase family, a group of natural enzymes, widely distributed in nature and found in plants and animals, including man. Their primary function is to catalyse the oxidation of certain molecules, at the expense of hydrogen peroxide, in order to generate reactive products with a wide antimicrobial activity. The presence of the pseudohalogen thiocyanate or a halogen as a second substrate (electron donor) is required to exert this antimicrobial effect (Reiter \& Härnulv, 1984; Reiter \& Perraudin, 1991). The peroxidases in the mammary, salivary and lachrymal glands are chemically and immunologically similar. The peroxidase isolated from milk was given the name lactoperoxidase and because of the above mentioned similarity other animal and human peroxidases are often referred to as lactoperoxidase (Reiter \& Härnulv, 1984). The biological significance of lactoperoxidase is its involvement in the natural host defence system against invading micro-organisms. In bovine milk it is one of the indigenous antimicrobial agents. Next to that antiviral activity, degradation of various carcinogens and protection of animal cells against peroxidative effects have been reported. The reaction products generated by the catalytic action of lactoperoxidase - in the so-called lactoperoxidase system - are harmless to mammalian cells (see review articles Reiter \& Härnulv, 1984; Reiter \& Perraudin, 1991; Wolfson \& Sumner, 1993; de Wit \& van Hooydonk, 1996).

\section{Physico-chemical properties}

A number of specific physico-chemical characteristics of bovine lactoperoxidase are summarised in Table 1.

Bovine LP consists of a single polypeptide chain containing 612 amino acid residues. Its amino acid sequence is known and the molecular weight is approximately $78 \mathrm{kDa}$. LP is a basic protein having a high isoelectric point of 9.6.

The LP molecule has a carbohydrate content of about 10 $\%$ and possesses five potential N-glycosylation sites. The observed chromatographic and electrophoretic heterogeneity of LP - at least ten fractions of LP were identified - is possibly due to changes during the isolation process. Some of the glycosidic fractions may be lost during the purification process and a partial deamidation may be also a cause of heterogeneity. Nevertheless there is no significant difference in enzymatic activity between the various LP fractions (Paul \& Ohlsson, 1985).

The haem group in the catalytic centre of the LP molecule is a protoporphyrin IX, covalently bound to the polypeptide chain through a disulphide bridge (Thanabal \& La Mar, 1989). This indicates that there is no free thiol group present in the enzyme molecule (Ekstrand, 1994).

The iron content of LP is $0.07 \%$, corresponding to one iron atom per LP molecule, being part of the haem group.

A calcium ion is strongly bound to LP, stabilising its molecular conformation and the calcium ion activity appeared to be of vital importance for the structural

* Corresponding author: K. D. Kussendrager, email kussendr@dmv-international.com 
Table 1. Physico-chemical characteristics of bovine lactoperoxidase

\begin{tabular}{lll}
\hline Characteristic & \multicolumn{1}{c}{ Data } & \multicolumn{1}{c}{ Reference } \\
\hline Molecular weight & $78431 \mathrm{Da}$ & Paul \& Ohlsson, 1985 \\
Amino acid residues & 612 & Cals et al. 1991 \\
Half cystine residues & 15 & Cals et al. 1991 \\
Carbohydrate content & $10 \%$ & Carlstrom, 1969 \\
Iron content & $0.07 \%$ & Paul \& Ohlsson, 1985 \\
Prosthetic group & haem : protoporphyrin IX & Thanabal \& La Mar, 1989 \\
Iso-electric point & 9.6 & Paul, 1963 \\
Secondary structure & $23 \% \alpha, 65 \% \beta, 12 \%$ unordered & Sievers, 1980 \\
Absorptivity $\varepsilon_{412} \mathrm{~nm}$ & $112 \cdot 3 \mathrm{mM}^{-1} \mathrm{~cm}^{-1}$ & Paul \& Ohlsson, 1985 \\
Absorptivity $280 \mathrm{~nm}$ & $14.9-15 \cdot 0,1 \%, 1 \mathrm{~cm}$ & Paul \& Ohlsson, 1985 \\
Redox potential $E_{\mathrm{m}}$ & $-191 \mathrm{mV}^{2}$ & Paul \& Ohlsson, 1985 \\
\hline
\end{tabular}

integrity of LP (Booth et al. 1989). Data about the folding structure of the polypeptide chain, in terms of percentage of $\alpha, \beta$ and unordered structures are given in Table 1 . The $3-$ dimensional structure of LP is in essence similar to that of myeloperoxidase (MPO), found in leucocytes of, for example mastitis milk (Zeng \& Fenna, 1992). An important difference between LP and MPO is the more constraint haem pocket of LP, being primarily responsible for the difference in halide specificity between MPO (MPO catalyses the oxidation of $\mathrm{SCN}^{-}, \mathrm{I}^{-}, \mathrm{Br}^{-}$and $\left.\mathrm{Cl}^{-}\right)(\mathrm{Hu}$ et al. 1993).

NMR studies have shown that $\mathrm{SCN}^{-}$and $\mathrm{I}^{-}$bind at the same position in the LP molecule and that $\mathrm{I}^{-}$binds more strongly (Modi et al. 1989).

The optical spectrum of LP Fe(III) shows a Soret band at $412 \mathrm{~nm}$ with an absorbance of $112.3 \mathrm{~mm}^{-1} \mathrm{~cm}^{-1}$. The absorbance at $280 \mathrm{~nm}(1 \%, 1 \mathrm{~cm})$ is $14 \cdot 9-15 \cdot 0$. Therefore, the theoretical $A_{412} / A_{280}$ ratio for pure LP solutions should be approximately 0.95 (Paul \& Ohlsson, 1985).

\section{Stability}

Thermal stability. Studies in milk, whey, permeate and buffer showed that heat denaturation of LP starts at temperatures from about $70^{\circ} \mathrm{C}$. The thermostability in permeate and buffer was less than that in whey or milk and the calcium ion concentration appeared to have a large influence on the heat sensitivity of LP. Thermal inactivation of the enzyme occurs close to the temperature at which the native structure of the enzyme unfolds and follows firstorder kinetics (Heràndez et al. 1990).

LP is less heat stable under acidic conditions $(\mathrm{pH} \mathrm{5.3),}$ possibly due to release of calcium from the molecule. Fig. 1 shows some results of thermal inactivation studies of LP in buffer and in raw milk (de Wit \& van Hooydonk, 1996).

$p H$. Systematic studies of time-dependent effects of extreme $\mathrm{pH}$ values on $\mathrm{LP}$ seem to be lacking. In the $\mathrm{pH}$ range $4 \cdot 4-6 \cdot 7$, at low LP concentartions ( 0.5 p.p.m.) the largest decrease of activity was observed at $\mathrm{pH} 5 \cdot 4,15 \%$

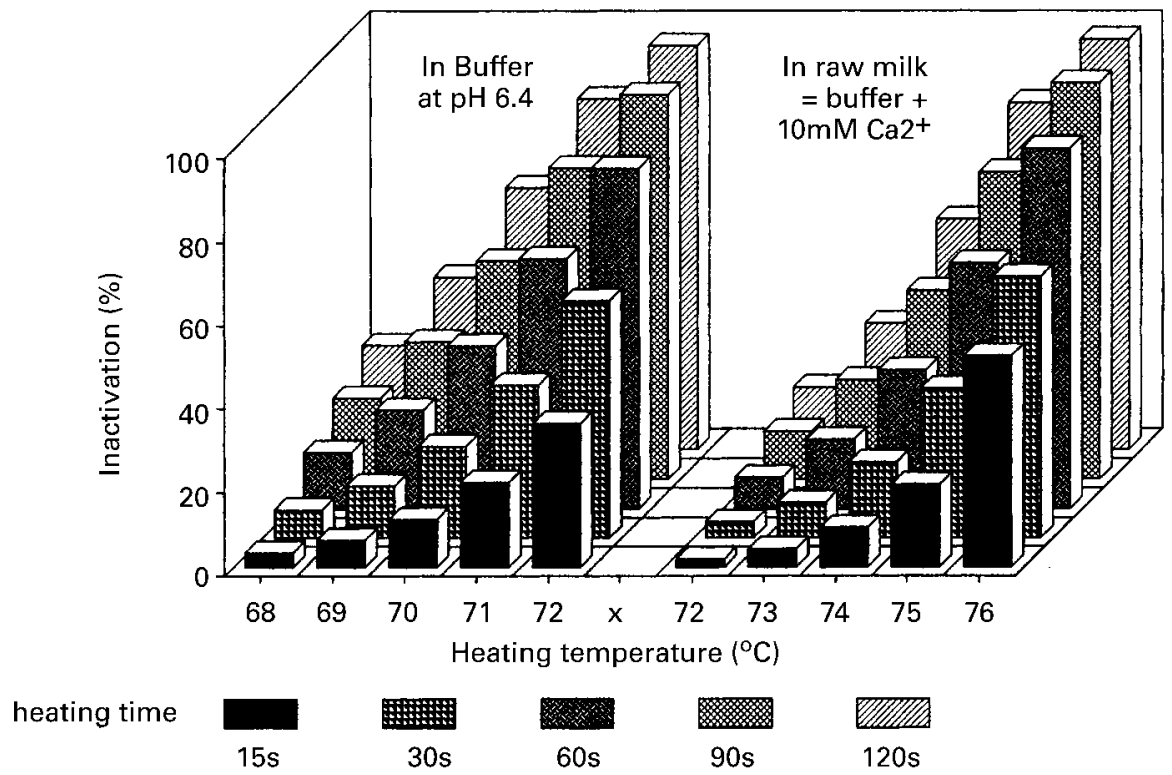

Fig. 1. Thermal inactivation of LP (50 p.p.m.) in acetate buffer ( $\mathrm{pH} 6.4)$, acetate buffer + calcium and raw milk. 
loss per 15 min, but at a concentration of 25 p.p.m. LP did not lose activity during $3 \mathrm{~h}$. This difference is probably due to adsorption of the enzyme to glass surfaces at low concentrations and indicates that the analyses have to be done quickly after the final dilution of the LP solution for the assay. LP is deactivated by storage at $\mathrm{pH} 3$ and some denaturation was observed at $\mathrm{pH}<4$. $\mathrm{pH}$ values up to about 10 seem not to inactivate LP at room temperature (Paul \& Ohlsson, 1985; Heràndez et al. 1990; de Wit \& van Hooydonk, 1996). The optimum $\mathrm{pH}$ of the LP catalysed reaction is studied using 2,2'-azinobis(3-ethylbenzylthiazoline-6-sulphonic acid (ABTS) as a substrate and lies between pH 5 and 6 , depending on the concentrations of ABTS and $\mathrm{H}_{2} \mathrm{O}_{2}$. One of the conclusions of this study was that for the determination of LP any $\mathrm{pH}$ value between 4.5 and 6.5 can be used (Bardsley, 1985).

Proteolytic enzymes. LP is rather resistant to proteolytic enzymes. It was reported that trypsin and thermolysin did not inactivate native LP and that chymotrypsin did so only very slowly. LP was not inactivated by the gastric juice of an infant ( $\mathrm{pH} 5$ ) but pepsin inactivated LP at $\mathrm{pH}$ $2 \cdot 5$. Native LP was rapidly digested by commercial pronase into fragments from which haem could be extracted (Sievers, 1979; Paul \& Ohlsson, 1985).

Photochemical inactivation. In the presence of riboflavin LP appears to be very sensitive to light. For example after exposure to 6000 lux for $4 \mathrm{~h}$ in the cold $\left(10^{\circ} \mathrm{C}\right)$, in milk, whey and permeate, LP was inactivated by $55 \%, 75$ $\%$ and $97 \%$, respectively. In buffer (50 p.p.m. LP), pH 6.7, no photochemical inactivation of LP occurred unless riboflavin was added. The photochemical inactivation was irreversible but could be prevented almost completely by addition of cysteine (Heràndez et al. 1990).

Aggregation and adsorption. It is reported that LP solutions easily become turbid and that the LP molecule has a high tendency to adhere to surfaces, which can cause a marked decrease in activity of dilute LP solutions in glass vessels. Adherence to surfaces may lead to aggregation and turbidity which seems to depend on the hydrophobicity of the surface. The enzyme is also firmly adsorbed by tooth enamel, as shown in a study with salivary LP. In this case the bound LP remains enzymatically active and was able to inactivate the glycolytic enzyme hexokinase.

The structural prerequisites for the aggregation and adsorption phenomena are largely unknown but the observations indicate that the LP molecule is equipped for both ionic and hydrophobic interactions (Paul \& Ohlsson, 1985).

\section{Concentration in milk and colostrum}

In bovine milk LP is, next to xanthine oxidase, the most abundant enzyme. Its concentration is around $30 \mathrm{mg} / \mathrm{l}$, constituting about $0.5 \%$ of the whey proteins (de Wit \& van Hooydonk, 1996).

Literature data for peroxidase activity vary widely and are difficult to compare, because of the various chromogens used for its assay and the variability in the assay conditions. Based on a detailed study of commonly used peroxidase assays a recommendation was given for the use of the assay, employing as chromophore 2,2'-azinobis(3-ethyl-
Table 2. Concentrations of $\mathrm{SCN}^{-}$in some human and bovine body fluids (Reiter \& Härnulv, 1984; Reiter \& Perraudin, 1991)

\begin{tabular}{lc}
\hline Fluid & $\mathrm{SCN}^{-}$concentration (p.p.m.) \\
\hline Human serum, adults & $1 \cdot 9-8 \cdot 4$ \\
saliva, adults & $37-198$ \\
saliva, infants & $15-22$ \\
gastric juice, adults & $22-64$ \\
gastric juice, infants & $6 \cdot 4$ \\
tear fluid & ca 10 \\
urine & $14-39$ \\
colostrum & $5 \cdot 0$ \\
milk & $2 \cdot 9$ \\
Bovine serum & $1 \cdot 2-16 \cdot 2$ \\
milk & $1 \cdot 2-15 \cdot 1$ \\
\hline
\end{tabular}

benzylthiazoline-6-sulphonic acid, (ABTS) (Pruitt \& Kamau, 1993). This is a very sensitive and nowadays the most commonly used chromogen for measuring (lacto)peroxidase activity.

In contrast to other antibacterial proteins, the LP concentration is low in bovine colostrum but increases rapidly to reach a maximum after 3-5 days postpartum (Korhonen, 1977). Thereafter, the level decreases slowly to reach a plateau after about 2 weeks, amounting to approx $50 \%$ of the maximum value reached after $3-5$ days postpartum.

Variations in enzyme level were reported to depend on the sexual cycle of the cow, season, feeding regime and breed (Kiermaier \& Kayser,1960; Reiter \& Perraudin, 1991).

Components of the lactoperoxidase system: $\mathrm{SCN}^{-}$and $\mathrm{H}_{2} \mathrm{O}_{2}$ $S C N^{-}$

The thiocyanate anion, $\mathrm{SCN}^{-}$, occurs ubiquitously in tissues and secretions of mammals. It is present in the mammary, salivary and thyroid glands and their secretions; in organs such as the stomach and kidney and in fluids such as synovial, cerebral, cervical, and spinal fluids, lymph and plasma. The concentrations depend partly on the feeding regime of the animal and eating and smoking habits of man. In bovine milk the $\mathrm{SCN}^{-}$concentration reflects blood serum levels and varies with breed, species, udder health and type of feed. Levels between 1 and 15 p.p.m. have been reported. Reported concentrations of $\mathrm{SCN}^{-}$in some human body fluids and in bovine serum and milk are given in Table 2 (Reiter \& Härnulv, 1984; Reiter \& Perraudin, 1991). Colostrum contains more $\mathrm{SCN}^{-}$, which is not surprising because the levels of blood proteins, sodium etc. are also higher than in milk.

Vegetables belonging to the genus Brassica, species of Cruciferae (cabbage, kale, cauliflower, etc.) are particularly rich in $\mathrm{SCN}^{-}$precursors such as the glucosinolates which upon hydrolysis produce $\mathrm{SCN}^{-}$, and/or isothiocyanate and nitriles. $\mathrm{SCN}^{-}$contents up to $600 \mathrm{mg} / \mathrm{kg}$ have been reported (Reiter \& Perraudin, 1991).

$$
\mathrm{H}_{2} \mathrm{O}_{2}
$$

This component of the lactoperoxidase system (LP-s) may 


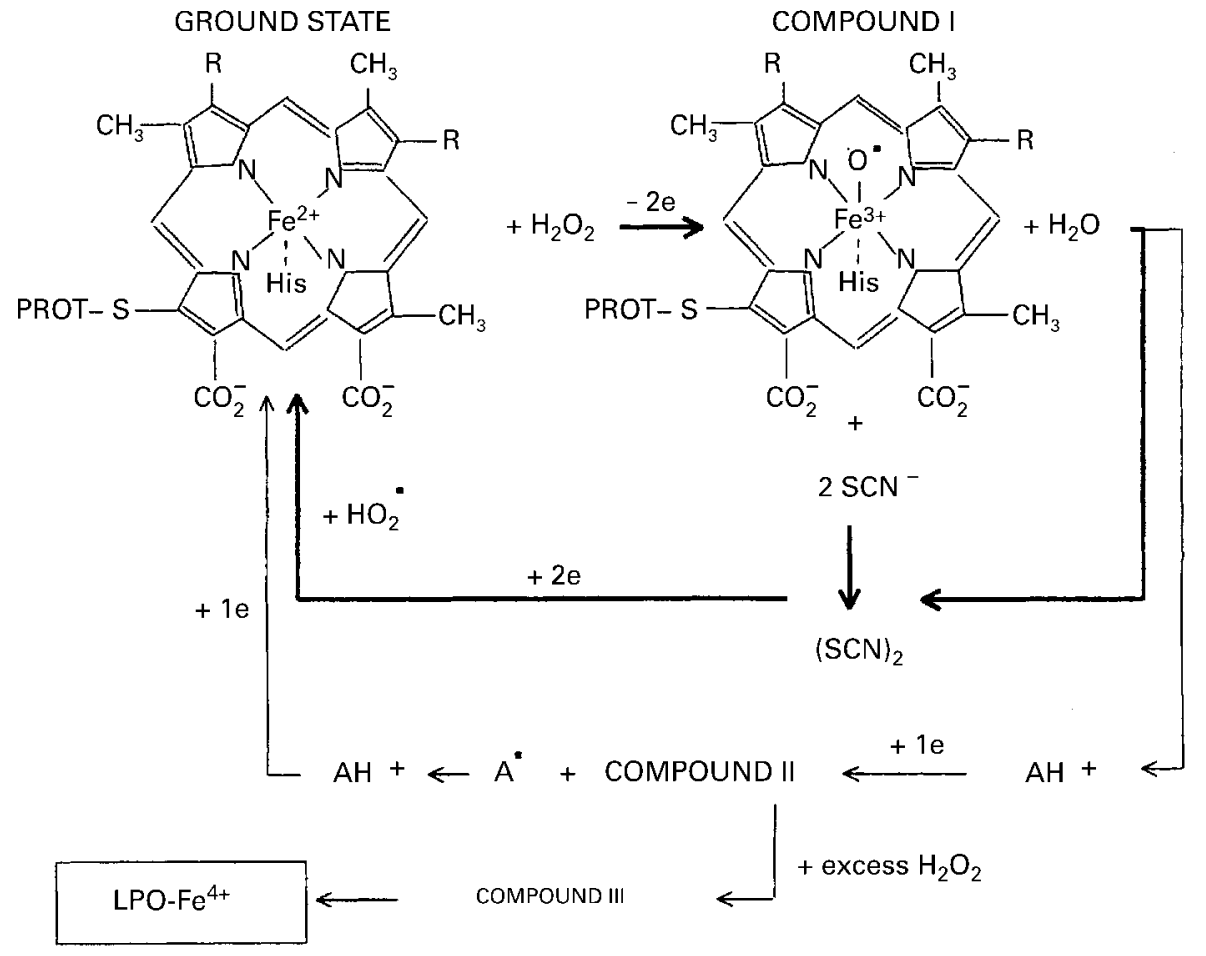

Fig. 2. Pathways in the lactoperoxidase-catalysed reaction mechanism.

be generated endogenously, e.g. by polymorphonuclear leucocytes (PMN) in the process of phagocytosis (Korhonen \& Reiter, 1983). Under aerobic conditions many lactobacilli, lactococci and streptococci may produce sufficient $\mathrm{H}_{2} \mathrm{O}_{2}$ to activate the LP-s. $\mathrm{H}_{2} \mathrm{O}_{2}$ can also be provided exogenously, by addition to the system as such or in a bound form (e.g. sodium percarbonate, magnesium peroxide). The use of $\mathrm{H}_{2} \mathrm{O}_{2}$-producing systems such as glucose oxidase/glucose and xanthine oxidase/hypoxanthine may provide a more effective antimicrobial LP-s than in the case of added $\mathrm{H}_{2} \mathrm{O}_{2}$ (Reiter \& Perraudin, 1991).

\section{Mechanism of action}

The LP enzyme catalyses the peroxidation of thiocyanate and some halides $\left(\mathrm{I}^{-}, \mathrm{Br}^{-}\right.$but not $\left.\mathrm{Cl}^{-}\right)$to generate products which kill or inhibit the growth of many species of micro-organisms. The reaction mechanisms are very complex.

A summary of the pathways of the enzymatic mechanism with $\mathrm{H}_{2} \mathrm{O}_{2}$ and $\mathrm{SCN}^{-}$is presented by de Wit \& van Hooydonk (1996). In brief the following reactions occur. The first step in the enzymatic mechanism is the initiation reaction of the resting $\mathrm{LP}\left(\mathrm{Fe}^{3+}\right)$ to its ground state, using $\mathrm{H}_{2} \mathrm{O}_{2}$, according to: $\mathrm{Fe}^{3+}+\mathrm{H}_{2} \mathrm{O}_{2} \rightarrow \mathrm{Fe}^{2+}+\mathrm{HO}_{2}$, followed by the propagation reactions, as illustrated in Fig. 2.

The propagation reactions include the conversion of LP from the ground state in to the so-called compound I state by reaction with $\mathrm{H}_{2} \mathrm{O}_{2}$. At low $\mathrm{SCN}^{-}(<3 \mu \mathrm{M})$ and halide concentrations compound I reacts with one-electron donors that are present (proteins peptides etc.) to form compound II, that is continuously reduced to the ground state at a low rate. At an excess of $\mathrm{H}_{2} \mathrm{O}_{2}(>0.5 \mathrm{~mm})$ compound II may react to form compound III, leading to a ferrylperoxidase adduct and to irreversible inactivation of LP. The agent that oxidises $\mathrm{SCN}^{-}$or halides is compound $\mathrm{I}$.

A proposed reaction scheme for the LP catalysed oxidation of $\mathrm{SCN}^{-}$, resulting in short-lived oxidation products, being responsible for the anti-microbial activity, is shown in Fig. 3 (de Wit \& van Hooydonk, 1996).

$\mathrm{OSCN}^{-}$is in equilibrium with HOSCN (hypothiocyanous acid) and at the $\mathrm{pH}$ of maximal LP activity ( $\mathrm{pH} 5 \cdot 3$ ) their amounts are equal. Both forms exert antibacterial activity but there is evidence that the uncharged HOSCN is more bactericidal. The stability of hypothiocyanite, $\mathrm{OSCN}^{-}$, is affected by many factors, such as $\mathrm{pH}$, light, metal ions ( $\mathrm{Fe}, \mathrm{Ni}, \mathrm{Cu}, \mathrm{Mn}$ etc.), glycerol and ammonium sulphate as well as by the presence and removal of LP, yet it is very heat stable (Thomas, 1985).

The oxidation of sulphydryl $(\mathrm{SH})$ groups of microbial enzymes and other proteins is considered to be the key to the antimicrobial action of the LP-system. This activity can be inhibited by reducing agents containing $\mathrm{SH}$ groups such as cysteine, glutathione, mercapto-ethanol, dithiothreitol and sodium hydrosulphite, either by direct binding to the haem group or by scavenging $\mathrm{OSCN}^{-}$. $\mathrm{HOSCN}$ and $\mathrm{OSCN}^{-}$appear not to oxidise $\mathrm{SH}$ groups of milk proteins such as $\beta$-lactoglobulin (de Wit \& van Hooydonk, 1996).

Hydrolysis of protein-S-SCN yields $\mathrm{SCN}^{-}$rather than HOSCN and the sulphenyl sulphur remains in the same oxidation state in a sulphenic acid derivative (R-SOH).

The structural damage of microbial cytoplasmatic membranes by the oxidation of $\mathrm{SH}$-groups results in leakage of potassium ions, amino acids and peptides into 


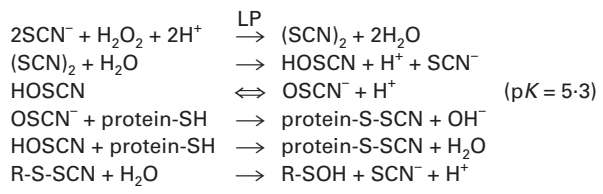

Fig. 3. Oxidation of protein (enzyme) sulphydryls by LP catalysed reactions, mediated by oxidation products of $\mathrm{SCN}^{-}$.

the medium and subsequently uptake of glucose, amino acids, purines, pyrimidines in the cell and synthesis of proteins, DNA and RNA is also inhibited (Reiter \& Härnulv, 1984; Reiter \& Perraudin, 1991).

\section{Antimicrobial activity of LP-s}

Different groups of bacteria show a varying degree of resistance to the LP-s. Gram-negative, catalase positive organisms such as pseudomonads, coliforms, salmonellae and shigellae are not only inhibited by the LP-s but, depending on medium conditions ( $\mathrm{pH}$, temperature, incubation time, cell density etc.), may be killed, provided $\mathrm{H}_{2} \mathrm{O}_{2}$ is supplied exogenously. Gram-positive, catalasenegative bacteria like streptococci and lactobacilli are generally inhibited but not killed by the activated LP-s. This difference in sensitivity to the LP-s can probably be explained by the differences in cell wall structure and their different barrier properties (Reiter \& Härnulv, 1984; Reiter \& Perraudin, 1991; de Wit \& van Hooydonk, 1996).

Mammalian cells are not affected by oxidation products of $\mathrm{SCN}^{-}$and it is suggested that the LP-s is not only atoxic to human cells but may protect these cells against toxic effects of $\mathrm{H}_{2} \mathrm{O}_{2}$ (Reiter \& Härnulv, 1984).

$\mathrm{I}^{-}$is the most readily oxidisable of all halides and the LP catalysed oxidation of $\mathrm{I}^{-}$yields $\mathrm{I}_{2}$ and, depending on $\mathrm{pH}$ and $\mathrm{I}^{-}$concentration, $\mathrm{HIO}$ and $\mathrm{IO}^{-}$are also present. When both $\mathrm{SCN}^{-}$and $\mathrm{I}^{-}$are present in LP-systems the reaction mechanism is more complicated. In biological fluids the $\mathrm{SCN}^{-} / \mathrm{I}^{-}$ratio is usually $10: 100$ and $\mathrm{SCN}^{-}$competes effectively with $\mathrm{I}^{-}$for LP catalysed oxidation, suggesting that the influence of $\mathrm{I}^{-}$would be negligible. However, $(\mathrm{SCN})_{2}$ oxidises $\mathrm{I}^{-}$to $\mathrm{I}_{2}$, so that oxidation of $\mathrm{SCN}^{-}$in the presence of $\mathrm{I}^{-}$might yield $\mathrm{I}_{2}$ indirectly. Oxidation of even small amounts of $\mathrm{I}^{-}$might be significant regarding the antimicrobial activity because the $\mathrm{LP}-\mathrm{H}_{2} \mathrm{O}_{2}-\mathrm{SCN}^{-}$system is primarily bacteriostatic whereas the $\mathrm{LP}-\mathrm{H}_{2} \mathrm{O}_{2}-\mathrm{I}^{-}$system is bactericidal. LP-systems with both $\mathrm{SCN}^{-}$and $\mathrm{I}^{-}$as electron donors are reported to be mostly bactericidal and also effective in killing a number of yeasts and moulds (Thomas, 1985; Guthrie, 1992).

\section{Applications}

The interest in developing the utilisation of LP/LP-systems as natural biopreservatives in food, feed specialties, cosmetics and related products has been increased considerably since the introduction of industrial processes for the recovery of LP from milk and whey. de Wit \& van Hooydonk (1996) reviewed a number of potential and actual applications of LP-systems and indicated their
Table 3. Some LP-s applications and their functionality (de Wit \& van Hooydonk, 1996)

\begin{tabular}{|c|c|c|c|}
\hline Product & LP-s added & Function & $\begin{array}{l}\text { Observed } \\
\text { results }\end{array}$ \\
\hline Raw milk & Natural & Preservation & 4 days $/ 4^{\circ} \mathrm{C}$ \\
\hline Raw milk & $\mathrm{SCN} / \mathrm{H}_{2} \mathrm{O}_{2}$ & Shelf life & 3 days $/ 10^{\circ} \mathrm{C}$ \\
\hline Pasteurised milk & $\mathrm{SCN} / \mathrm{H}_{2} \mathrm{O}_{2}$ & Shelf life & 21 days $/ 10^{\circ} \mathrm{C}$ \\
\hline Cheese milk & $\mathrm{SCN} / \mathrm{H}_{2} \mathrm{O}_{2}$ & Shelf life & 8 days $/ 4-7^{\circ} \mathrm{C}$ \\
\hline Yoghurt & LP & Suppress acidity & 14 days $/ 20^{\circ} \mathrm{C}$ \\
\hline Emulsions & $\mathrm{LP} / \mathrm{KI} / \mathrm{GO}$ & Preservation & 14 days $/ 20^{\circ} \mathrm{C}$ \\
\hline Cosmetics & LP/KI/SCN/GO & Preservation & $2-4$ months \\
\hline Dentifrice & LP/SCN/LYS/GO & Healing & Daily \\
\hline Ophthalmics & LP/KI/SCN/GO & Protection & 1 week \\
\hline Anti-tumour & LP/GO/antibody & Healing & Periodical \\
\hline
\end{tabular}

LP, lactoperoxidase; LP-s, lactoperoxidase system; GO, gluclose oxidase; LYS lysozyme.

composition and functionality. These are summarised in Table 3.

\section{Some actual applications of LP-systems}

A number of the applications listed in Table 3 are explored commercially nowadays and some of these will be referred to in more detail.

Nakada et al. (1996) studied the effect of the addition of LP to starter cultures used for yoghurt production from pasteurised milk. They found that at a final LP concentration in the yoghurt of 5 p.p.m. the acid production in the yoghurt was suppressed almost completely during a storage period of 14 days at $10^{\circ} \mathrm{C}$ without affecting the viable count of the culture bacteria dramatically. They suggested that at the low SCN-concentrations present and the low $\mathrm{H}_{2} \mathrm{O}_{2}$ levels produced by the lactic acid bacteria the resulting low activity of the LP-s at the low temperature of $10^{\circ} \mathrm{C}$ only inhibited acid production of the bacteria and did not exert a bacteriostatic effect. They concluded that addition of LP produced a new type of yoghurt which retains acceptable quality during storage for at least two weeks (see also Dosako, 1991). A number of LP supplemented yoghurts have been on the market for several years. It has been observed (de Wit \& van Hooydonk, 1996) that, in cases where $\mathrm{SCN}^{-}$concentrations in high temperature/short time (HTST $90^{\circ} \mathrm{C} / 2 \mathrm{~min}$ )-pasteurised milk are too low, addition of $\mathrm{SCN}^{-}$and $\mathrm{H}_{2} \mathrm{O}_{2}$ may be a very effective and reliable means of inhibition of postacidification in yoghurt, as illustrated in Fig. 4.

Guthrie (1992) reported the application of the LP-s for preservation of cosmetics and concluded that a LP-s can provide a broad spectrum antimicrobial activity against bacteria, yeasts and moulds when it is composed of LP, $\mathrm{H}_{2} \mathrm{O}_{2}, \mathrm{SCN}^{-}$and $\mathrm{I}^{-}$at carefully selected weight ratios. Optimum results were obtained when $\mathrm{H}_{2} \mathrm{O}_{2}$ is generated enzymatically by the glucose oxidase-glucose system.

This application is also described by Godfrey (1990) and has resulted in the development and commercial presentation of the optimised system for use in cosmetic preservation (Boots MicroCheck, 1992).

Hoogendoorn (1985) reported that activation of salivary peroxidase antimicrobial system in toothpaste and mouthrinse reduces acid formation by oral micro-organisms and 


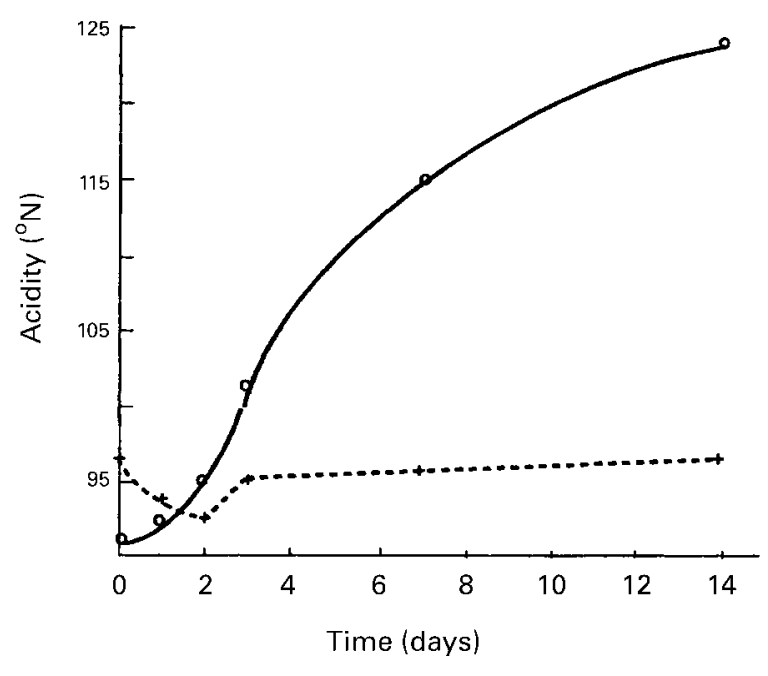

Fig. 4. Effect of LP-system on postacidification of stirred yoghurt at $10^{\circ} \mathrm{C}$. $\mathrm{o}=$ control, $+=$ after addition of lactoperoxidase (10 p.p.m.), $\mathrm{SCN}^{-}(0.2 \mathrm{~mm})$ and $\mathrm{H}_{2} \mathrm{O}_{2}(0.6 \mathrm{~mm})$ after fermentation. (de Wit \& van Hooydonk, 1996)

clinical studies have shown that plaque accumulation, gingivitis and early carious lesions and aphthous lesions may all be reduced by appropiate applications of the applied enzyme preparations. The application of LPsystems with LP and oxidases like glucose oxidase in dentifrices have been described (Pellico \& Montgomery, 1989) and oral care products containing complete LPsystems have been on the market for a number of years.

The possibilities for applications of LP-systems in aquaculture to improve yield by its bactericidal action on fish pathogens have been explored. Next to the strong bactericidal in vitro effects on fish pathogenic bacteria studies in vivo also showed a positive effect of LP-s supplemented feed on the resistance of rainbow trout fry against bacterial infections, resulting in a significant reduction of mortality in the weaning period (K Kussendrager, unpublished results).

\section{Conclusion}

The LP-system can be regarded as a very active and natural antimicrobial system without undesirable side-effects.

The availability of industrial processes, for the isolation of LP from bovine milk and whey, has resulted in a growing interest in the valorisation of the LP-s as a biopreservative in a wide range of products.

Although a number of applications for the LP-s are already exploited commercially, further growth in the utilisation of LP and LP-systems, in a broad field of food and non-food products, can be expected.

The natural biological functions of the LP-s and the increasing pressure to restrict the use of chemical antimicrobials are considered as important driving forces behind this growth.

\section{References}

Bardsley WC (1985) Steady-state kinetics of lactoperoxidasecatalysed reactions. In The Lactoperoxidase System, Chemistry and Biological Significance, pp. 55-83 [KM Pruit and JO Tenovuo, editors]. New York: Marcel Dekker.

Booth KS, Kimura S, Lee HC, Ikeda-Saito M \& Caughey WS (1989) Bovine myeloperoxidase and lactoperoxidase each contain a high affinity binding site for calcium. Biochemical and Biophysical Research Communications 160, 879-902.

Boots MicroCheck (1992) Natural biocide comes fresh from the dairy. Cosmetics \& Toiletries Manufacturers \& Suppliers (CTMS) 6-2, 35 .

Cals MM, Mailliart P, Brignon G, Anglade P \& Ribadeau Dumas B (1991) Primary structure of bovine lactoperoxidase, a fourth member of a mammalian heme peroxidase family. European Journal of Biochemistry 198, 733-738.

Carlstrom A (1969) Lactoperoxidase, Identification of multiple molecular forms and their relationships. Acta Chemica Scandinavica 23, 171-184.

de Wit JN \& van Hooydonk ACM (1996) Structure, functions and applications of lactoperoxidase in natural antimicrobial systems. Netherlands Milk \& Dairy Journal 50, 227-244.

Dosako S (1991) Lactic acid bacterium starter containing peroxidase, fermented milk product, and production thereof. European Patent Application EP 0521166 A1.

Ekstrand B (1994) Lactoperoxidase and lactoferrin. In Natural Antimicrobial Systems and Food Preservation, pp. 15-63 [VM Dillon and RG Board, editors]. Wallingford: CAB International.

Godfrey DC (1990) Anti-microbial compositions. European Patent Specification EP 0514417 B1.

Guthrie WG (1992) A novel adaptation of a naturally occurring antimicrobial system for cosmetic protection. SOFW-Journal 118, 556-562.

Heràndez CMM, van Markwijk BW \& Vreeman HJ (1990) Isolation and properties of lactoperoxidase from bovine milk. Netherlands Milk and Dairy Journal 44, 213-231.

Hoogendoorn H (1985) Activation of the salivary peroxidase antimicrobial system: clinical studies. In The Lactoperoxidase System, Chemistry and Biological Significance, pp. 217-227 [KM Pruitt and JO Tenovuo, editors]. New York: Marcel Dekker.

Hu S, Treat RW \& Kincaid JR (1993) Distinct heme active-site structure in lactoperoxidase revealed by resonance raman spectroscopy. Biochemistry 32, 10125-10130.

Kiermeier F \& Kayser C (1960) Zur Kenntnis der Lactoperoxidase. Zeitschrift für Lebensmittel-Untersuchung und-Forschung 112, 481-498.

Korhonen H (1977) Antimicrobial factors in bovine colostrum. Journal of the Scientific Agriculture Society of Finland 49, 434-447.

Korhonen HJ \& Reiter B (1983) Production of $\mathrm{H}_{2} \mathrm{O}_{2}$ by bovine blood and milk polymorphonuclear leucocytes. Acta Microbiologica Polonica 32, 53-64.

Modi S, Behere DV \& Mitra S (1989) Binding of thiocyanate to lactoperoxidase: ${ }^{1} \mathrm{H}$ and ${ }^{15} \mathrm{~N}$ nuclear resonance studies. Biochemistry 28, 4689-4694.

Nakada M, Dosako S, Hirano R, Ooka M \& Nakajima I (1996) Lactoperoxidase suppresses acid production in yoghurt during storage under refrigeration. International Dairy Journal 6, 3342.

Paul KG (1963) Peroxidases. In The Enzymes, pp. 27-274 [PD Boyer, H Lardy and K Myrback, editors]. New York: Academic Press.

Paul KG \& Ohlsson PI (1985) The chemical structure of lactoperoxidase. In The Lactoperoxidase System, Chemistry 
and Biological Significance, pp. 15-29 [KM Pruitt and JO Tenovuo, editors]. New York: Marcel Dekker.

Pellico MA \& Montgomery RE (1989) Di-enzymatic dentrifice. European Patent Specification EP 0133736 B1.

Pruitt KM \& Kamau DN (1993) Quantitative analysis of bovine lactoperoxidase system components and of the effects of the activated system on bacterial growth and survival. In Proceedings of the IDF Seminar Indigenous Antimicrobial Agents of Milk, Recent Developments, pp. 73-87.

Reiter B \& Härnulv G (1984) Lactoperoxidase antibacterial system: natural occurrence, biological functions and practical applications. Journal of Food Protection 47, 724-732.

Reiter B \& Perraudin JP (1991) Lactoperoxidase: biological functions. In Peroxydases in Chemistry and Biology, pp. 143180. Boca Raton: CRC Press.

Sievers G (1979) The prosthetic group of milk peroxidase is protehym IX. Biochimica et Biophysica Acta 579, 181-190.
Sievers G (1980) Structure of milk lactoperoxidase. A study using circular dichroism and difference absorption spectroscopy. Biochimica et Biophysica Acta 624, 249-259.

Thanabal V \& La Mar GN (1989) A nuclear Overhauser effect investigation of the molecular and electronic structure of the heme crevice in lactoperoxidase. Biochemistry 28, 7038-7044.

Thomas EL (1985) Products of lactoperoxidase-catalyzed oxidation of thiocyanate and halides. In The Lactoperoxidase System, Chemistry and Biological Significance, pp. 31-53 [KM Pruitt and JO Tenovuo, editors]. New York: Marcel Dekker.

Wolfson LM \& Sumner SS (1993) Antimicrobial activity of the lactoperoxidase system. A review. Journal of Food Protection 56, 887-892.

Zeng J \& Fenna RE (1992) X-ray crystal structure of canine myeloperoxidase at $3 \AA$ resolution. Journal of Molecular Biology 226, 185-207. 